الجمعية المصرية للقر اعة والمعرفة عضو الجمعية الدولية للمعرفة

\title{
Zagazig University
}

Faculty of Education

Curricula \& Instruction Department

Utilizing a Strategy Based on the Mastery Learning Approach to Enhance EFL Oral Communication Skills and Self-Efficacy of Secondary Stage Students

\author{
MA Thesis
}

By

Eman Abd Ellateef Mohammed Abd Ellateef

An EFL Teacher

Supervisor

Prof. Dr. Mohammed Hassan Ibrahim

Professor of Curricula \& Instruction

Faculty of Education

Zagazig University

AD AH -2020 -1441 


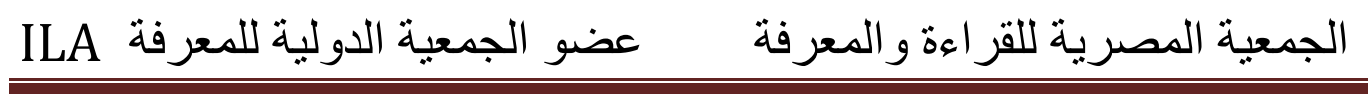




\section{الجمعية المصرية للقر اعة والمعرفة عضو الجمعية الدولية للمعرفة ILA}

\section{Abstract}

The current study targeted at enhancing EFL oral communication skills and selfefficacy of the first secondary stage students through the mastery learning-based strategy. To achieve the purpose of this study, the researcher adopted the quasiexperimental design. The study participants involved (60) students from the first Mixed Secondary School, Al- year secondary stage students from Al-Ibrahimia Ibrahimia Directorate, Sharkia Governorate, Egypt. They were randomly allocated in two groups. A number of (30) students represented the study participants in the experimental group and (30) students for the control group. The study was conducted over a period of (6) weeks, along (15) sessions from "New Hello Book" assigned for the first year secondary stage students over the second semester of the academic year (2019/2020). To gather data, the researcher designed four instruments represented in; a checklist of the most appropriate EFL oral communication skills necessary for the first year secondary stage students, an EFL oral communication skills test, a rubric to score the test, and a five-point Likert scale for measuring the effect of the mastery learning-based strategy on the students' self-efficacy. These instruments were submitted to a panel of EFL jury members to check their validity. These instruments were administrated before and after the treatment to both the experimental and control groups. Data were collected and analyzed statistically. The results revealed that there is a statistically significant difference between the mean scores of the experimental group and that of the control group in their oral communication skills and self-efficacy in favor of the experimental group. Findings of the current study were ascribed to the mastery learning-based strategy that provided evidence for its positive effect on enhancing the first year secondary stage students and on their self-efficacy. In the light of these findings, some relevant recommendations and suggestions for further research were provided.

Key Words: EFL Oral Communication Skills, Self-Efficacy, Mastery LearningBased Strategy. 


\section{Introduction}

Language is a means for communication which involves mastering the language four main skills: listening, speaking, reading, and writing. We communicate with others to express our ideas and to know others' ideas as well. Language is one way of communication requiring the use of sound and symbols. It is through language that people share views and feelings through written and spoken methods. Language and communication are at the heart of human experience.

As emphasized by Lazaraton (2002), one of the main aims in learning a language, specifically a second or foreign language, is the ability to communicate effectively in the language. Oral communication refers to communicating orally in a way which is obvious, fluent, and to the point, and which grasps the audience attention, both in group and in one-to-one situations. Ashour (2014) assured that one of the most challenges teachers learners face in many EFL classes is communicating fluently. It is assumed that the difficulties that hinder proper oral communication are summarized in cultural differences, personal differences, deficit of students' confidence and motivation, insufficient time specified for oral preparation and performance, and the absence of interest of the oral discussion topics. Consequently, acquiring and performing oral communication skills require more practice in various situations.

Furthermore, it is clear that students' affective variables play a key role and effective impact on students' success and on their foreign language learning. Among these affective variables, self-efficacy is known to have an essential role in academic success of students. Self-efficacy is an extremely significant aspect in students' academic performance. As assumed by Zimmerman (2001), there are many aspects can enhance or decrease students' self-efficacy such as: personal effects, behavioral effects, and environmental effects. Gahungu also (2007) summarized a number of factors known to influence self-efficacy and potentially foster it. These factors are 
goal determination, information processing, models, encouragement $\&$ feedback, and rewards.

Despite the urgent significance and positive impact of self-efficacy as revealed though paramount bulks of previous studies, some students proved to lack self-efficacy beliefs and suffer from the low levels of self-efficacy to EFL oral communication.

Consequently, the current study intended to enhance EFL oral communication skills and self-efficacy among the study participants through using a strategy based on the mastery learning approach.

\section{Literature Review and Related Studies}

Communication as defined by Rahman (2010) is a dynamic interactive process that includes the influential transmission of facts, thoughts, emotions, and values. It is active process and does not just happen; we actively and consciously engage in communication process in order to get, develop, ask, and give information and understanding is required for effective group functioning. Bohlke (2014) pointed out four skill areas of speaking competence are required for effective communication. First, the phonological skills in which learners need to be able to blend the phonemes of the language they are learning. Additionally, they have to use accurate stress and intonation. Second, the speech functions in which learners need to accomplish particular communicative functions in social and transactional exchanges such as agreeing with someone, asking for clarification or justifying a reason. Third, the interactional skills which mean that in face-to-face exchanges, students must manage interactions through regulating turn taking, redirecting the topic, and negotiating meaning, in addition to initiating, pursuing and ending a conversation. Fourth, the extended discourse skills in which learners must produce long stretches of uninterrupted speech and they need to structure what they say to make it easy for others to follow.

Samantaray (2014) pointed out that sometimes English language teaching does not fulfill its goals. Even after years of English teaching, the learners do not have the confidence of using the 
language in and outside the classroom. Genuine communication involves thoughts, emotions, feelings, suitability, and adaptability. The regular English class hardly gives the learners a chance to use language in this manner and develop fluency in it. Thus, the main aim of the language teaching course, i.e., improving communication skills, is unfortunately, ignored. Teacher's aim in practicing oral English is to enhance student's ability to communicate freely and spontaneously. To attain this aim, teachers need to arrange activities in pairs and groups, to grant students the opportunity to use language in face-to-face interactive situations. They need to create a situation to teach language in an active and interesting manner as using regular methods cannot create enough motivation and interest in EFL learners.

The significance of oral communication skills cannot be underestimated. Effective oral communication skills are necessary in all walks of life. The lack of good communication skills has a negative effect both on the personal as well as professional life of a person (Narayanrao, 2012). (Barrass, 2006) suggested that certainly everyone needs good communication skills in everyday life conversations, for learning at school, at university, or even at work. Additionally, learners are in a need for it in their future career based on their previous studies. Some students spent about twelve years at school trying to develop their writing skills, yet they neglected improving their abilities to converse, to address an audience, so they are suffering from the inability to express themselves or their ideas clearly and effectively in English. Educational courses at schools should be intended to develop students' EFL communication skills and to develop other interpersonal skills pertinent to enhancing their English.

Loubazid (2012) stated that teachers always focus on the importance to teach the linguistic aspects of the language particularly grammar and phonology and ignore speaking skills which is in fact an essential aspect in communication. Speaking is a productive skill; it 
requires a lot of practice to improve an acute sense of competence and mastery of this skill. Teaching speaking in a non-English speaking country is much challenging as English is totally different from Arabic language. During the oral sessions, teachers use different activities and strategies to empower student' speech, brush up their English, and enhance them to well pronounce and utter appropriately; however, teachers still confront some students' hindrances. Many students do not participate in oral discussions, do not contribute, and do not show any sign of progress which refer that there is something wrong somewhere with students.

The researcher tried to connect developing EFL oral communication skills of the first year secondary stage students with their selfefficacy beliefs.

Bandura (1997) defined self-efficacy as the persons' beliefs in their capabilities to produce desired impacts by their own actions. He also defined that self-efficacy as a persons' confidence in their capacities to arrange and execute actions to achieve their goals set, and attempt to evaluate the level and strength in all activities and contexts. (Choi,2005) confirmed that self-efficacy has a big effect on students at schools or colleges as it assists them to foster their academic achievement. Generally, when learners believe in their academic competences, it aids them to decide about what they have learnt and mediate a construct through which prospective educational experiences are interpreted.

Self-efficacy is an essential entity in elevating someone to a better level. Individuals without self-efficacy will not be able to confront difficulties in life. Self-efficacy beliefs are crucial aspects of human motivation and behavior as they affect the individuals' action. They indicate to a belief about one's abilities to learn or perform at designated levels. (Pajares, 2002).

Numerous studies revealed a strong correlation between self-efficacy and academic performance. Researches confirmed that when 
students believe they are capable of accomplishing an academic task, they are far more likely to persist and overcome difficulties to successfully perform the task. Moreover, when students lack the confidence in their capabilities to perform a task or overcome a challenge, they are more likely give up and may even go out of their way to avoid the assignment.

According to Barkley (2005), research revealed that students with high levels of self-efficacy possess more willingness to participate; they work harder and longer, and have less negative emotional reactions when they compete in comparison to students with low levels of self-efficacy. In order to enhance self-efficacy in struggling students, teachers can model for those students helping them to acquire the necessary skills and efficacy beliefs that motivate them to complete a given task. Once students start to accomplish a specific task consistently, their efficacy beliefs are likely to increase. Mede \& Kararrmak (2017) focused on the correlations between foreign language speaking anxiety and demographic factors among undergraduate students. The study focused on anticipating the roles of speaking anxiety and English self-efficacy on foreign language speaking anxiety. Finally, the results showed strong correlation between speaking anxiety and English self-efficacy on foreign language speaking anxiety. Based on those results, the study suggested some implications about how to decrease foreign language speaking anxiety.

One of the strategies the researcher investigated in an attempt to enhance EFL oral communication skills and self-efficacy among $1^{\text {st }}$ year secondary graders is the mastery learning group-based strategy. It is a pedagogical approach that was developed by Benjamin Bloom in the 1970s to overcome many learning issues resulted from conventional methods in teaching. 
Adeyemo (2014) defined Mastery Learning Approach (MLA) is an instructional approach, where students are granted unlimited opportunities to demonstrate mastery of content taught. It includes breaking down the subject matter to be learned into small units of learning, each with its own objectives. It also allows students to have enough time to master the prerequisites before achieving success and moving towards progress. Bloom's mastery learning theory is a group-based method. It differs from regular classroom instruction in that:

1. It stresses mastery of all objectives in each learning unit.

2. It uses diagnostic progress test (formative tests A\&B) to identify each learner's mistakes.

3. It uses the systematic feedback i.e. correctives for assisting learners overcome learning difficulties.

4. Finally, it gives additional time for those learners who need it, emphasizes on variation in learning-time and permits high level of achievement for all learners. Traditional instruction holds time constant and allows mastery to vary while mastery learning holds mastery constant and allows time to vary, (Obidiegwu \& Ajibare, 2007).

Shafie et al. (2010) reported that mastery learning had been proven to be positive particularly in the achievement aspect, attitudes towards learning, and the retention of the content in a subject matter undertaken by the students .Mastery learning is potentially beneficial for the students at several aptitude levels. It is especially useful to low aptitude students whose past experiences with failures on the subject matter have diminished their motivation and desire regarding the subject matter.

Subramanya et al. (2017) stated that mastery learning also has the merit of elaborating on the principles behind the task and defining the end points of that task, which makes learning clearer. It provides proficiency targets, which promote deliberate practice and technical 
skill acquisition. The trainees who adopt this strategy tend to develop a mindset, which focuses on proficiency rather than meeting a set target number for a particular procedure. Mastery learning brings about behavioral advantages that include positive change in attitude, nature of approach to a problem, spirit to achieve one's best and beyond, and sense of rising to the challenge. It involves systematic, precise pedagogies that show supervisors concrete measurable evidence of trainees' learning.

The mastery learning strategy permits students to study material unit after unit until they achieve the units' mastery. Mastery of each unit is appeared when the student acquires the set pass mark of a diagnostic test. MLA assists the student to acquire targeted skills and objectives before moving to the next unit. The teacher is also required to analyze tasks and state the objectives before specifying the activities. MLA can help teachers to know students' areas of weakness and work on correcting them which in turn breaking the cycle of failure. MLA has the unique quality of enabling mastery of content by the student through supplementary instruction and corrective activities of small units of the subject matter.

(Wambugu\&Changeiywo, 2008).

To sum up, the researcher concluded that mastery learning has deep roots in educational field. It is based on the concept that all students can learn when provided with conditions appropriate to their situation. Students must reach a predetermined level of mastery on one unit before they are allowed to progress to the next one. In a mastery learning setting, students are given specific feedback about their learning progress at regular intervals throughout the instructional period. This feedback helps students identify what they have learned well and what they have not learned well. Areas that were not learned well are allotted more time to achieve mastery.

\section{Context of the Problem}

Despite the importance of EFL oral communication skills, the $1^{\text {st }}$ year secondary graders suffer from a lack in their EFL oral 
performances. Out of the researcher's experience in teaching, it has been noticed that there are a lot of problems that obstacles that hinder the oral communication process as they are unable to speak fluently. Additionally, they speak slowly and take too long period to compose utterances. They cannot participate actively in oral practices. They have low motivation and low self-efficacy to speak. To document the problem of the study, a pilot study (EFL oral test \&self-efficacy scale) was conducted on fifty students of first year secondary stage at Al-Ibrahimia Secondary School, Sharkia Governorate. Results revealed that there was a lack in students' EFL oral communication skills and a decrease in their self-efficacy beliefs.

\section{Statement of the Problem}

The problem of this study could be stated in the poor performance of the first year secondary stage students' EFL oral communication skills and their low self-efficacy levels to communicate as revealed by the pilot study results conducted by the researcher. Therefore, this study was an attempt to enhance their oral communication skills and self-efficacy in communication through utilizing the mastery learning-based strategy which proved to be useful and effective in this concern.

\section{Questions of the Study}

The current study was an attempt to address the following main question:

"What is the effectiveness of utilizing a strategy based on the mastery learning approach in enhancing EFL oral communication skills and self-efficacy of secondary stage students?"

Five sub-questions were derived from this main question: 
1. What are the main EFL oral communication skills required for the first year secondary stage students?

2. To what extent do the first year secondary school students perform EFL oral communication skills successfully?

3. What are procedures of utilizing the mastery learning strategy to enhance EFL oral communication skills and self-efficacy of the first year secondary stage student?

4. What is the effectiveness of utilizing the mastery learning strategy on enhancing EFL oral communication skills of the first year secondary stage students?

5. What is the effectiveness of utilizing the mastery learning strategy on enhancing self-efficacy of the first year secondary stage students?

\section{Aims of the Study}

The present study basically aimed at:

1. Enhancing some EFL oral communication skills of the first year secondary stage students through utilizing the mastery learning based strategy.

2. Enhancing self-efficacy of the first year secondary stage students through utilizing the mastery learning based strategy.

3. Identifying the effectiveness of the mastery learning-based strategy on EFL oral communication skills and self-efficacy of secondary stage students.

\section{Significance of the Study:}

This study could be helpful to:

1. EFL students: 
It helped EFL students to enhance their achievement levels, raising their self- efficacy towards communicating in English language, and creating interactive creative classroom environment.

2. EFL teachers:

It provided EFL teachers with an effective model to use in teaching EFL oral communication skills. It was also useful in presenting a suitable instrument to measure the EFL students' oral communication skills and self-efficacy.

3. EFL supervisors:

It might provoke EFL supervisors conducting training courses for the EFL teachers encouraging them to adopt the mastery learning approach in their language classrooms as it makes a balance between fast and low learners.

4. EFL curricula designers and textbook authors:

It was an attempt to assist the curricula designers and textbook authors to take into consideration the principles and propositions of the mastery learning approach while designing communicative tasks to be included in students' textbooks as a means of fostering their overall oral communication proficiency and self-efficacy which may be widely beneficial through using various audio and visual techniques.

5. EFL researchers:

It paved the way for other researchers to conduct further studies on using the mastery learning approach in teaching other EFL skills and enhancing the students' self-efficacy in these skills.

\section{Delimitations of the Study:}

This study was delimited to:

1. Five EFL oral communication skills appropriate to the first year secondary stage students as validated by the jury members. These main skills were (accuracy, fluency, listening comprehension, pragmatic skills, and strategic skills). These five main skills included other pertinent sub-skills 
2. A five point Likert self-efficacy scale.

3. The mastery learning-based strategy (Bloom's Model) to teach EFL oral communication skills required for the first year secondary stage students.

4. A simple randomly chosen sample comprised of sixty students of the first year secondary stage students at Al-Ibrahimia Mixed Secondary School, Al-Ibrahimia Directorate, Sharkia Governorate. Thirty students were for the experimental group, and thirty students were for the control group.

5. The second semester of the school year (2019/2020).

\section{Procedures of the Study}

To answer the questions of the current study, the following procedures were deployed consecutively as follows:

1. Reviewing the literature and previous studies related to the study variables (EFL oral communication skills, self-efficacy, and mastery learning approach).

2. Designing the study instruments that included :

- Preparing an EFL oral communication skills questionnaire appropriate for the first year secondary stage students.

- Submitting it to a panel of jurors and TEFL specialists to verify and determine the most important appropriate EFL oral communication skills required for the first year secondary stage students.

- Modifying the skills checklist based on the jury's feedback and setting it in its final form.

- Constructing an EFL oral communication pre-posttest and a rubric for scoring.

- Submitting them to TEFL jurors to check their validity and reliability.

- Modifying them according to the jury's opinions. 
- Preparing a five-point Likert scale measure the participants' self-efficacy.

- Submitting it to the jury members to be validated.

3. Selecting the study participants randomly of first year secondary stage students at Al-Ibrahimia Mixed School, Al-Ibrahimia Directorate, Sharkia Governorate, and dividing them into two groups (30) in the experimental group and (30) in the control group.

4. Pre-administering the oral communication test to both groups to evaluate the students' actual standard concerning these skills before the experiment.

5. Pre-administering the self-efficacy scale to both groups to identify the students' actual self-efficacy beliefs before the experiment

6. Instructing the experimental group using the experimental treatment material (mastery learning strategy); while the control group is taught through the regular method.

7. Post administering the oral communication test to both groups after the intervention to measure the effect of the mastery learning-based strategy.

8. Post administering the self-efficacy scale to measure the effect of the mastery learning-based strategy.

9. Comparing the results of pre-post administrations, collecting, and organizing the obtained data.

10. Conducting the suitable statistical data analysis.

11. Interpreting and discussing the results.

12. Providing conclusions, recommendations, and suggestions for further research.

\section{Study Terminology}




\section{EFL Oral Communication Skills}

Al Saleem (2018) mentioned that oral skills are realized as the total responses that were produced by humans in different linguistic contexts; they are also viewed as instruments to reveal what is going learners' minds communicate with others. In addition, they are viewed as strong connectors in the instructional process.

\section{In this study EFL oral communication skills can be operationally} defined as the first year secondary grade students' ability to convey and receive the meanings in meaningful oral coherent structures. It is the capacity to perform the targeted oral skills fluently, accurately, and properly in interactive communicative situations without hesitation, undue pauses or restrictions according to a range of different functions in different contexts.

\section{Self-Efficacy}

Self-efficacy is that people's thinking way and function that is assisted by someone's logic of control. People will be more devoted to their decisions when they entirely believe that they can resolve problems. In this context, self-efficacy is linked to personal control, support and action. Therefore, humans can enjoy their life if they think that they can do more things with self-determined. Selfefficacy affects the way people work their minds, act and feel. It has relation to worry, stress and weakness (Schwarzer, 2014).

In this study self-efficacy can be operationally defined as the first year secondary stage students' belief in their capacities to execute communicative behaviors and situational tasks necessary to produce specific performance attainments. In this study, self-efficacy was the effective reaction occurs among the students after being exposed to the mastery- based learning strategy (Bloom's model).

\section{Mastery Learning}

Mastery learning was defined by Kazu, et al. (2015 p.7) as that kind of learning in which the learners got a lot of achievement until they reach the high levels of knowledge. Each learner's works according 
to his/her own capacity and readiness. The learner reaches to the ultimate goal in the educational material.

In this study mastery learning can be operationally defined as an instructional group-based strategy (Bloom's Model) utilized to help the first year secondary stage students acquire, perform, and enhance specific oral communicative skills included in New Hello English book of the $1^{\text {st }}$ year secondary stage. Through this strategy they acquire the required oral communication skills and perform them individually, in pairs or in groups in accordance with every learner achieving level and self-pacing up to the level of mastery.

\section{Findings of the Study}

To determine whether students overall oral communication skills were developed after implementing the experimental treatment using the mastery learning strategy, the hypotheses of the study were tested by using the Statistical Package for Social Sciences (SPSS version 26) Program.

The general results of the current study confirmed that:

1. There is a statistically significant difference between the mean scores of the experimental and the control groups in the post administration of the EFL oral communication test, in favor of the experimental group.

The following figure (1) shows that the mean scores of experimental group students are higher than those of the control one in the posttest in oral communication skills. 


\section{الجمعية المصرية للقر اءة والمعرفة عضو الجمعية الدولية للمعرفة}

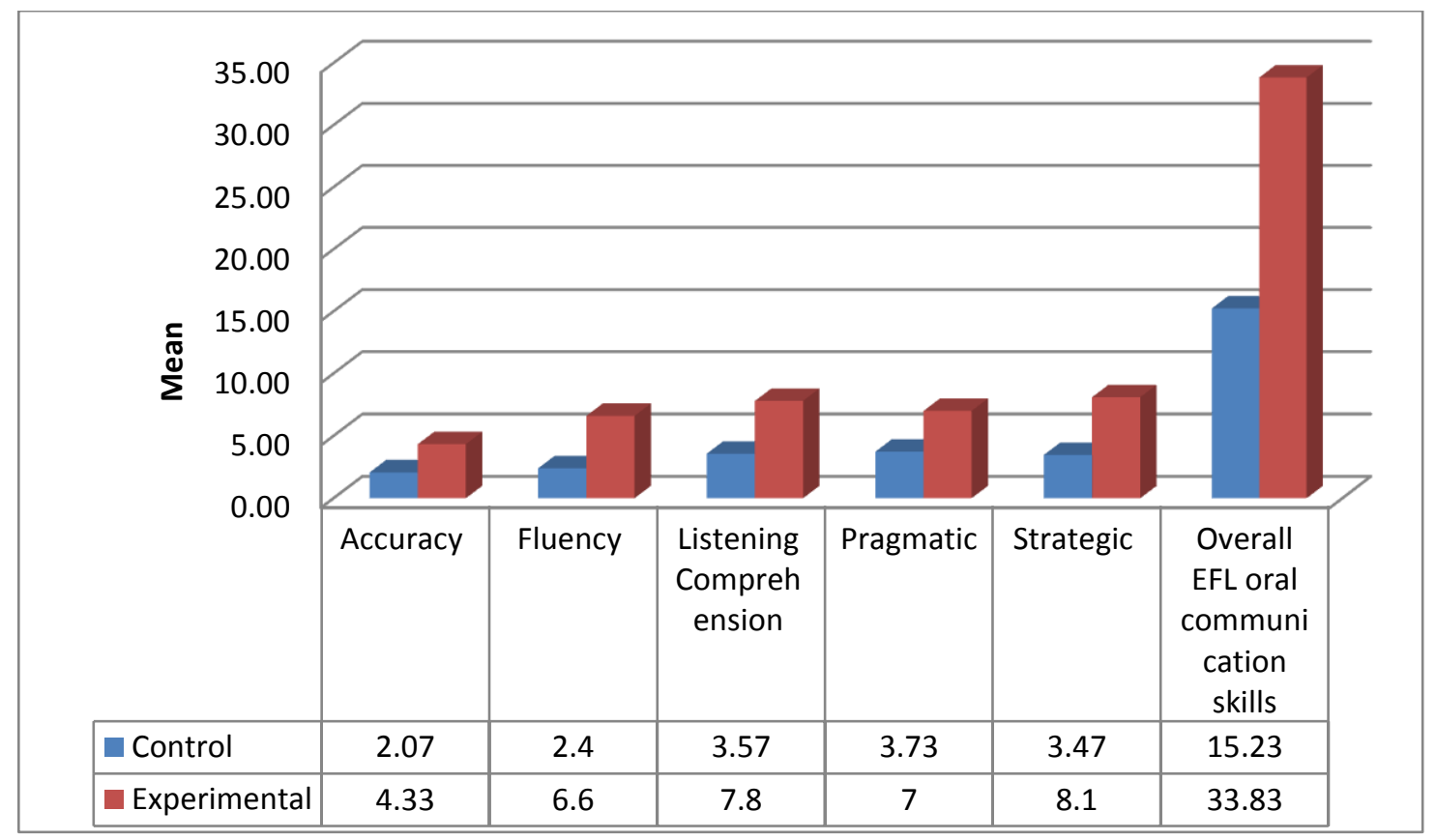

2. There is a statistically significant difference between the mean scores of the experimental group in the pre and post administrations of the EFL oral communication test in favor of the post administration.

The following figure (2) shows the differences between the experimental in the pre and posttest of overall EFL oral communication skills and its sub-skills. 


\section{ILA الجمعية المصرية للقر اءة والمعرفة عضو الجمعية الدولية للمعرفة}

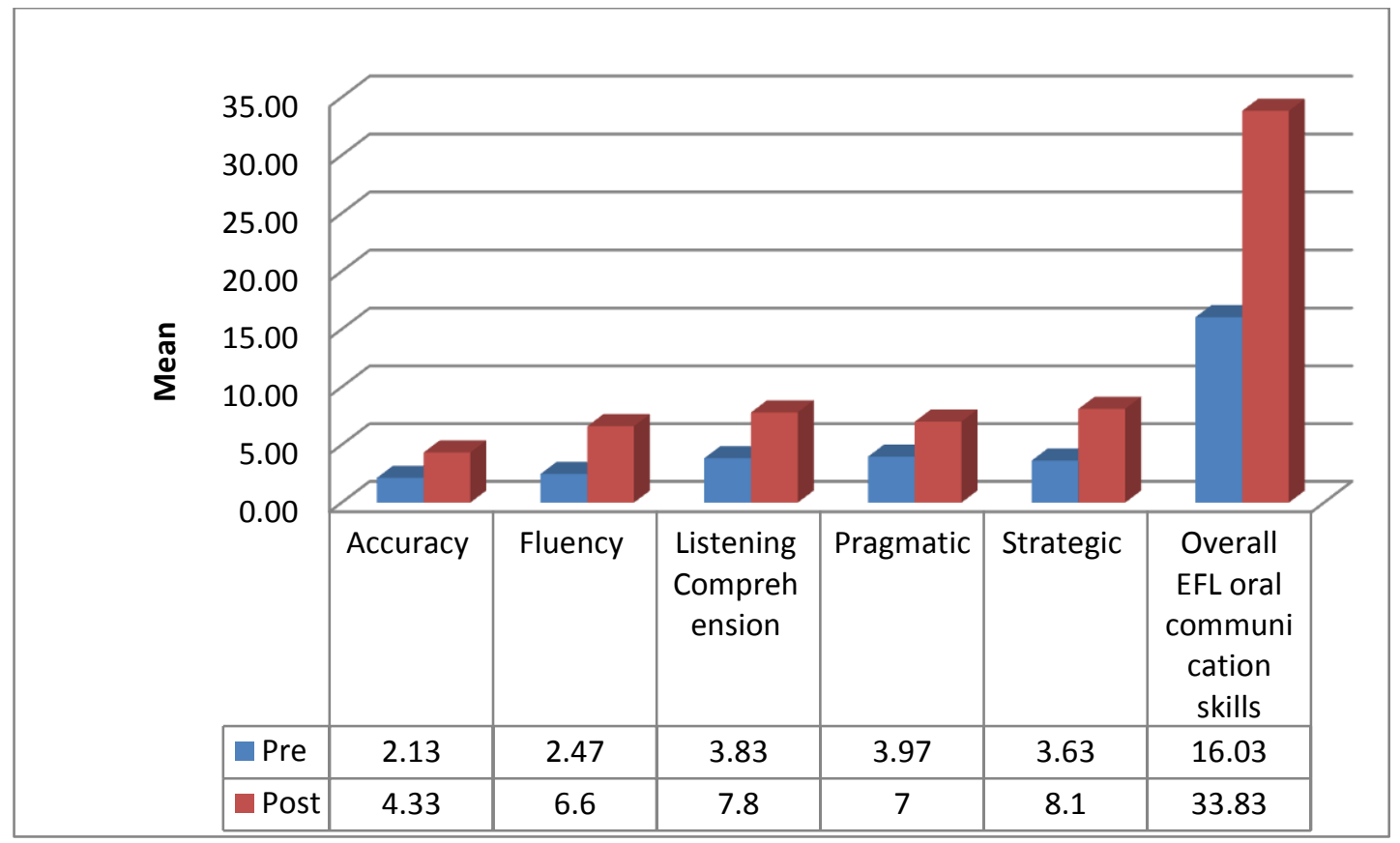

3. There is a statistically significant difference between the mean scores of the control group and the experimental group in the post administrations of self-efficacy scale in favor of the experimental group.

The following figure (3) shows the differences between the experimental in the pre and post administration of overall SelfEfficacy scale. 


\section{الجمعية المصرية للقر اعة و المعرفة عضو الجمعية الدولية للمعرفة ILA}

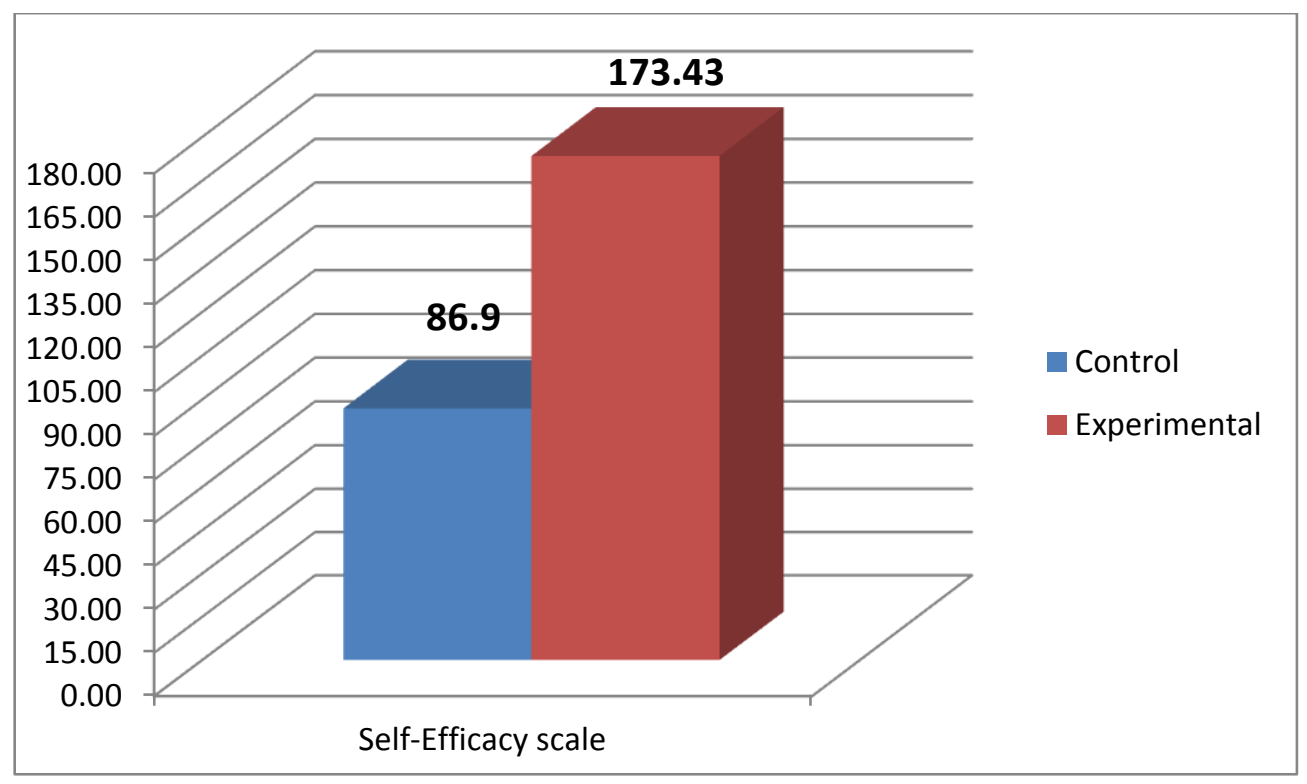

4. There is a statistically significant difference between the mean scores of the experimental group in the pre and post administrations of self-efficacy scale in favor of the post administration.

The following figure (4) shows that the mean scores of experimental group students in post administration are higher than those in the pre-administration in self-efficacy scale.

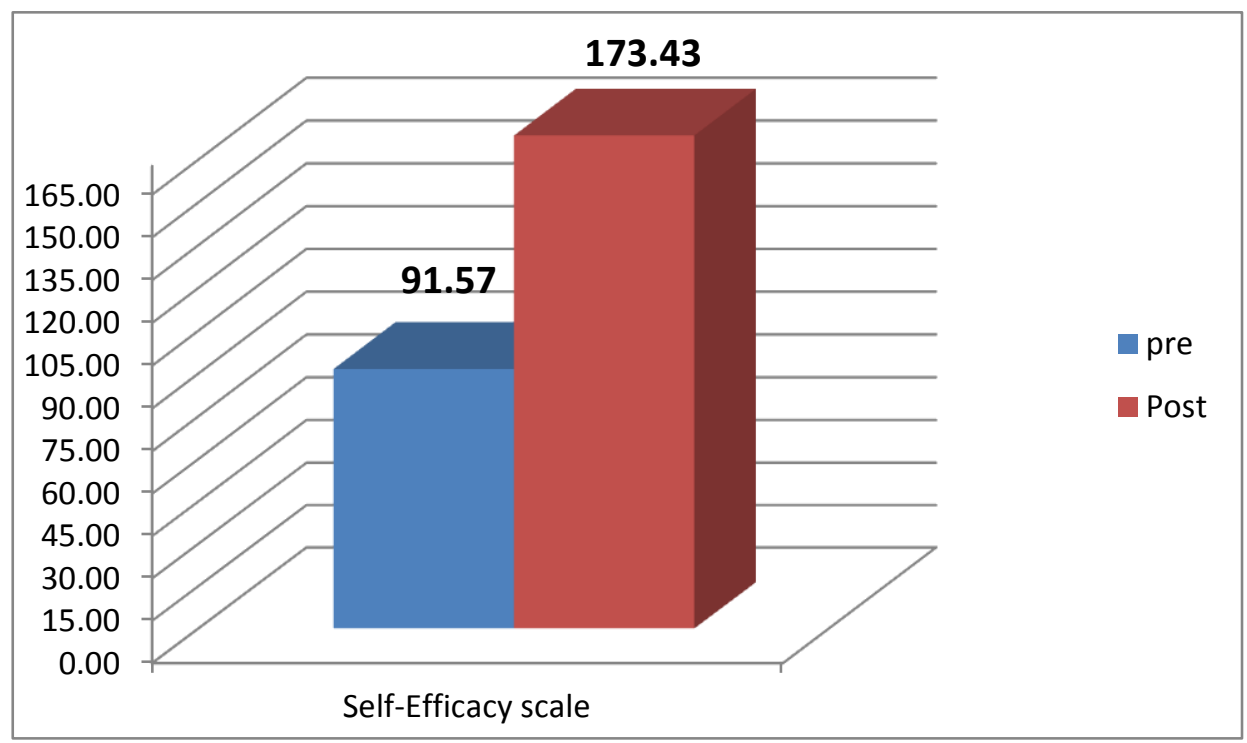


5. The strategy based on the mastery learning approach has a positive effect on enhancing the experimental group EFL oral communication skills. To verify this hypothesis, the researcher calculated the effect size by using the paired sample t-test to compare the scores of the experimental group in EFL oral communication skills in the pre and the posttest using Cohen's formula as shown in the following table (1)

\begin{tabular}{|c|c|c|c|c|c|c|c|}
\hline Skill & Test & $\mathbf{N}$ & $\mathbf{M}$ & S.D & $\mathbf{T}$ & $\begin{array}{r}\text { Eta } \\
\text { square }\end{array}$ & $\begin{array}{r}\text { Effect } \\
\text { size }\end{array}$ \\
\hline \multirow[t]{2}{*}{ 1-Accuracy Skills } & Pre & 30 & 2.13 & 0.571 & \multirow[t]{2}{*}{16.86} & \multirow[t]{2}{*}{0.783} & \multirow{2}{*}{$\begin{array}{l}\text { I.V } \\
\text { Large }\end{array}$} \\
\hline & Post & 30 & 4.33 & 0.606 & & & \\
\hline \multirow[t]{2}{*}{ 2- Fluency Skills } & Pre & 30 & 2.47 & 0.629 & \multirow[t]{2}{*}{19.40} & \multirow[t]{2}{*}{0.887} & \multirow{2}{*}{$\begin{array}{r}r . \wedge \\
\text { Large }\end{array}$} \\
\hline & Post & 30 & 6.60 & 0.855 & & & \\
\hline \multirow{2}{*}{$\begin{array}{r}\text { 3-Listening } \\
\text { Comprehension } \\
\text { skills }\end{array}$} & Pre & 30 & 3.83 & 0.699 & \multirow[t]{2}{*}{20.37} & \multirow[t]{2}{*}{0.852} & \multirow{2}{*}{$\begin{array}{r}r . r \\
\text { Large }\end{array}$} \\
\hline & Post & 30 & 7.80 & 0.961 & & & \\
\hline \multirow[t]{2}{*}{ 4-Pragmatic Skills } & Pre & 30 & 3.97 & 0.718 & \multirow[t]{2}{*}{14.33} & \multirow[t]{2}{*}{0.771} & \multirow{2}{*}{$\begin{array}{r}\text { I.^ } \\
\text { Large }\end{array}$} \\
\hline & Post & 30 & 7.00 & 0.947 & & & \\
\hline \multirow[t]{2}{*}{ 5-Strategic Skills } & Pre & 30 & 3.63 & 0.928 & \multirow[t]{2}{*}{26.10} & \multirow[t]{2}{*}{0.873} & \multirow{2}{*}{$\begin{array}{r}\text { Y. } \\
\text { Large }\end{array}$} \\
\hline & Post & 30 & 8.10 & 0.803 & & & \\
\hline \multirow{2}{*}{$\begin{array}{r}\text { Overall EFL oral } \\
\text { communication } \\
\text { skills }\end{array}$} & Pre & 30 & 16.03 & 2.31 & \multirow[t]{2}{*}{30.89} & \multirow[t]{2}{*}{0.944} & \multirow{2}{*}{$\begin{array}{c}\text { ¿. } 1 \\
\text { Large }\end{array}$} \\
\hline & Post & 30 & 33.83 & 2.10 & & & \\
\hline
\end{tabular}

According to the findings of Cohen's formula and the indicated that $\leqslant$.) interpretations of the effect size, the percentage 
a strategy based on the mastery learning approach had an effect on improving the students' EFL oral communication skills.

6. The strategy based on the mastery learning approach has a positive effect on enhancing the experimental group self-efficacy. To verify this hypothesis, the researcher calculated the effect size by using the paired sample t-test to compare the scores of the experimental group in the pre and the post administration of selfefficacy scale using Cohen's formula as clarified in the following table (2)

\begin{tabular}{|r|r|r|r|r|r|r|r|}
\hline Skill & Administration & N & M & S.D & T & $\begin{array}{r}\text { Eta } \\
\text { square }\end{array}$ & $\begin{array}{r}\text { Effect } \\
\text { size }\end{array}$ \\
\hline \multirow{2}{*}{ Self-Efficacy scale } & Pre & 30 & 91.57 & 11.47 & \multirow{2}{*}{32.84} & 0.934 & $\begin{array}{r}\text { Y. } \\
\text { Large }\end{array}$ \\
\cline { 2 - 8 } & Post & 30 & 173.43 & 10.60 & & & \\
\hline
\end{tabular}

According to the findings of Cohen's formula and the interpretations of the effect size, the percentage 3.7 indicated that a strategy based on the mastery learning approach had an effect on enhancing the students' self-efficacy.

Consequently, it can be concluded that utilizing a strategy based on the mastery learning approach was effective in enhancing EFL oral communication skills and self-efficacy of the first year secondary stage students.

\section{Recommendations of the Study}

In the light of the study findings, the following recommendations can be presented:

1. EFL teachers should adopt the communicative approach and include oral interactive and communicative activities in their teaching instructions. This may encourage students to form a positive self-image, improve their autonomy, and raise their selfefficacy to participate in the classroom activities. 
2. To maximize the cycle of students' participation in the classroom, it is recommended for teachers to make a previous assessment of the students' needs and interests in order to include the most appropriate topics and activities that facilitate the students' engagement and participation.

3. It would be beneficial if teachers grant students with accuracy and fluency development activities in each of the four main language skills (listening, speaking, reading, and writing).

4. Teachers should sustain and provoke their learners to produce oral output in a variety of appropriate genres that match the students' needs, interests, and linguistic proficiency levels such as engaging in communicative tasks in a range of situations, conducting discussions, making presentation, role-playing activities, and using pair and group work etc...

5. Since self-efficacy is one of the most influential factors in EFL learning, especially oral skills as confirmed in the present study, it is very important for the teachers to help students to develop their selfefficacy. Teachers can enhance the students' levels of self-efficacy by several ways such as giving them tasks that they can perform, provide them opportunity to build successful experiences, give them positive feedback and encouragement, and make them think positively that with effort and determination, they can succeed.

\section{Suggestions for Further Research}

Based on the results of the present study, the following suggestions research were presented: for further

1. Exploring the effectiveness of the mastery learning instruction in developing students' listening comprehension skills.

2. Examining the effectiveness of mastery learning strategy in enhancing EFL a reading to writing performance.

3. Identifying the impact of the mastery learning strategy on improving EFL vocabulary acquisition and its retention process. 4. Identifying the effectiveness of the mastery learning strategy in developing the translation competence of EFL learners. 
ILA الجمعية المصرية للقز اعة والمعرفة عضو الجمعية الدولية للمعرفة

\section{References}

Adeyemo, S.A. (2014). Effects of Mastery Learning Approach on Students' Achievement in Physics. International Journal of Scientific \& Engineering Research, 5(2), February2014, ISSN 22295518, $910-920$.

Ashour, J.M. (2014). "The Effect of Using a VideoconferencingBased Strategy on UNRWA 9th Graders' English Speaking Skills and their Attitudes towards Speaking". Published M.A. Thesis, The Islamic University of Gaza, Palestine.

Bandura, A. (1997). Self-Efficacy: The Exercise of Control. New York: W. H. Freeman and Company.

Barkley, J. M. (2005). Efficacy Beliefs and Reading Comprehension: Relations between Middle Grades Teacher' and Students' Efficacy Beliefs, Outcome Expectancies, and Students' Reading Comprehension Performance, Auburn University, ProQuest Dissertations Publishing, 1-13, Retrieved from:

https://search.proquest.com/openview/9e61765a13a7093d5a89dc9ec $\underline{535 \mathrm{~b} 06 \mathrm{~d} / 1 \text { ?pq-origsite }=\mathrm{gscholar} \& \mathrm{cbl}=18750 \& \text { diss }=\mathrm{y}}$

Barrass. R., (2006). Speaking for Yourself, A guide for students, Routledge, Taylor\& Francis Group.

Bohlke, D. (2014). Fluency Oriented Second Language Teaching , In M. Celce-Murica, D.Brinton, and M.A. Snow (eds) Teaching English as a Second or Foreign Language. $\left(4^{\text {th }}\right.$ ed). Boston: National Geographic Learning. M.Celce-Murica. 
Choi, N. (2005). Self- efficacy and self- concept as predictors of college students' academic performance. Psychology in the Schools, 42(2), 197-205.

Gahungu, O. N. (2007). The Relationships among Strategy Use, SelfEfficacy, and Language Ability in Foreign Language Learners.

Published Ph.D, Faculty of Education, Curriculum and Instruction Department, Northern Arizona University.

Lazaraton, A. (2002). A qualitative approach to the validation of oral language testing, Studies in language testing 14. Cambridge: Cambridge University Press.

Loubazid, M. (2012). Exploring the Difficulties Facing EFL Students' Participation in Oral Expression Course. Published MA thesis, Biskra University, Algeria

Mede, E , Karairmak, Ö . (2017). The Predictor Roles of Speaking Anxiety and English Self Efficacy on Foreign Language Speaking Anxiety, Journal of Teacher Education and Educators, 6 (1), 11713, Retrieved from

https://dergipark.org.tr/tr/pub/jtee/issue/43270/525680

Narayanrao, H. (2012). A study on Communication Skills in English as Life-Line to All, Asian Journal of Management Research, 3(1), 20-21

Pajares, F. (2002). Overview of Social Cognitive Theory and SelfEfficacy, Emory University, Retrieved December 2012 from: http://www.uky.edu/ eushe2/Pajares/eff.html

Rahman, M. M. (2010). Teaching Oral Communication Skills: A Task-based Approach. ESP World, 1 (27) volume 9, 1-11. Available at: http://www.esp-world.info 
Samantaray, P. (2014). Dramatization as a method of developing spoken English skill. International Journal of Language \& Linguistics, 1(1), 70-78.

Shafie, N., Shahdan, T. N. T., \& Liew, M. S. (2010). Mastery Learning Assessment Model (MLAM) in Teaching and Learning Mathematics. Procedia-Social and Behavioral Sciences, 8, .294-298.

Subramanya, M. S. ,Smith, S. \& Lonie, J.(2017). Mastery learning: How Is It Helpful? An Analytical Review." Advances in Medical Education and Practice, Dove Press Journal , 8, 269-275, DOI: 10.2147/AMEP.S131638

Wambugu, P. W., \& Changeiywo, J. M.\& Wachanga, S.W. (2008). Effects of Mastery Learning Approach on Secondary School Students' Physics Achievement. Eurasia Journal of Mathematics, Science \& Technology Education, 4(3), 293-302

Zimmerman, B. J., \& Schunk, D. H. (2001). Self-Regulated Learning and Academic Achievement: Theoretical Perspectives ( $2^{\text {nd }}$ ed.). Mahwah, NJ, US: Lawrence Erlbaum Associates Publishers. 